\title{
Green Technology: Bacteria-Based Approach Could Lead to Unsuspected Microbe-Plant-Animal Interactions
}

\author{
Daniela Bulgari $^{1,2}$, Matteo Montagna ${ }^{1}\left[\right.$, Emanuela Gobbi ${ }^{2} \mathbb{D}$ and Franco Faoro ${ }^{1, *(\mathbb{C})}$ \\ 1 Department of Agricultural and Environmental Sciences-Production, Landscape, Agroenergy, University \\ of Milan, Italy, via Celoria 2, 20133 Milan, Italy; daniela.bulgari@gmail.com (D.B.); \\ matteo.montagna@unimi.it (M.M.) \\ 2 Piattaforma di Microbiologia Agroalimentare ed Ambientale (Pi.Mi.A.A.), AgroFood Lab, Department of \\ Molecular and Translational Medicine, University of Brescia, 25121 Brescia, Italy; emanuela.gobbi@unibs.it \\ * Correspondence: franco.faoro@unimi.it
}

Received: 14 December 2018; Accepted: 2 February 2019; Published: 6 February 2019

check for updates

\begin{abstract}
The recent and massive revival of green strategies to control plant diseases, mainly as a consequence of the Integrated Pest Management (IPM) rules issued in 2009 by the European Community and the increased consumer awareness of organic products, poses new challenges for human health and food security that need to be addressed in the near future. One of the most important green technologies is biocontrol. This approach is based on living organisms and how these biocontrol agents (BCAs) directly or indirectly interact as a community to control plant pathogens and pest. Although most BCAs have been isolated from plant microbiomes, they share some genomic features, virulence factors, and trans-kingdom infection abilities with human pathogenic microorganisms, thus, their potential impact on human health should be addressed. This evidence, in combination with the outbreaks of human infections associated with consumption of raw fruits and vegetables, opens new questions regarding the role of plants in the human pathogen infection cycle. Moreover, whether BCAs could alter the endophytic bacterial community, thereby leading to the development of new potential human pathogens, is still unclear. In this review, all these issues are debated, highlighting that the research on BCAs and their formulation should include these possible long-lasting consequences of their massive spread in the environment.
\end{abstract}

Keywords: plant microbiome; pathogens; trans-kingdom; biostimulants; biocontrol

\section{Introduction}

Biocontrol is defined as the use of living organisms to control pests, also resulting in plant growth promotion [1,2] (Table 1). This approach to pest containment has experienced a revival in the last decade because of the new guidelines for the Common Agricultural Policy (Dir 128/2009) issued in 2009 by the European Community. This directive contains the Integrated Pest Management (IPM) principles (annex III), one cornerstone of which is the promotion of sustainable biological, physical, and other non-chemical methods instead of chemical ones, whenever they provide satisfactory pest control. A greater emphasis on IPM as part of agricultural policy has been giving new input in developing commercial products based on living organisms, with a particular interest in those isolated from rhizosphere, soil, or plant phyllosphere and endosphere. 
Table 1. Terminology and definitions related to biocontrol field.

\begin{tabular}{|c|c|c|}
\hline Term & Definition & Reference \\
\hline Biocontrol & $\begin{array}{l}\text { The use of living organisms to control plant pathogens and } \\
\text { pests resulting in plant growth promotion }\end{array}$ & [2] \\
\hline Biostimulants & $\begin{array}{l}\text { Formulated products with novel, or emergent properties } \\
\text { due the complex of constituents, that improve plant } \\
\text { productivity not as a sole consequence of the presence of } \\
\text { known essential plant nutrients, plant growth regulators, or } \\
\text { plant protective compounds }\end{array}$ & [3] \\
\hline Biopesticide & $\begin{array}{l}\text { Biological pesticides are derived from natural materials } \\
\text { including plants, animals and microbe, and some minerals }\end{array}$ & [4] \\
\hline Biofertilizer & $\begin{array}{l}\text { A biofertilizer is any bacterial or fungal inoculant applied to } \\
\text { plants with the aim of increasing the availability of nutrients } \\
\text { and their utilization by plants, regardless of the nutrient } \\
\text { content of the inoculant itself. Biofertilizers may also be } \\
\text { defined as microbial biostimulants improving plant } \\
\text { nutrition efficiency. }\end{array}$ & [5] \\
\hline Phytostimulator & $\begin{array}{l}\text { Microorganism with the ability to produce or change the } \\
\text { concentration of growth regulators, such as indole acetic } \\
\text { acid, gibberellic acid, cytokinins, and ethylene }\end{array}$ & [6] \\
\hline Pathogen & $\begin{array}{l}\text { A microbe that can cause physiological and structural } \\
\text { damages in a host }\end{array}$ & [7] \\
\hline Biocontrol agents & $\begin{array}{l}\text { Living organisms that show the ability to directly or } \\
\text { indirectly antagonize plant pathogens and pests }\end{array}$ & here defined \\
\hline Endophytic bacteria & $\begin{array}{l}\text { Bacteria that habit for all or part of their lifetime, in the } \\
\text { internal part of a plant }\end{array}$ & [8] \\
\hline Plant microbiome & $\begin{array}{l}\text { A community of microbes associated with a plant and their } \\
\text { crosstalk with the plant genome and proteome }\end{array}$ & [9] \\
\hline Pathobiome & $\begin{array}{l}\text { The complex interactions of pathogenic microbes which may } \\
\text { influence or drive disease processes and their relationship to } \\
\text { the 'normal' microbiome of the organism in question }\end{array}$ & {$[10,11]$} \\
\hline Phytonoses & $\begin{array}{l}\text { New group of diseases caused by human pathogens that are } \\
\text { transmitted via consumption of fresh produce }\end{array}$ & {$[12,13]$} \\
\hline
\end{tabular}

The first-generation of commercial biocontrol products, mainly based on Bacillus and Pseudomonas species, were characterized by low efficacy to control plant diseases in open fields [14,15]. The failure of these products was possibly due to the lack of knowledge about (i) biocontrol mechanisms, (ii) plant-microbe interactions, and (iii) selection procedures for active biocontrol strains $[14,16]$. Biocontrol of plant diseases is a complex process involving not only the biocontrol agent (BCA), the plant, and the pathogen but also the environment, the genetic determinants, and the indigenous microflora (Table 1). Therefore, the effectiveness of BCAs is related to many factors such as their ability to colonize, survive, and proliferate for a considerable time inside and/or on plant tissues in the presence of indigenous microflora and, at the same time, directly or indirectly antagonize phytopathogens [15]. Furthermore, commercial BCAs, registered as such (see ahead), should have some additional properties, i.e., easiness of formulation, the ability to effectively colonize the host and survive in the agricultural environment, and not being pathogenic for non-target organisms [17]. Bacteria can directly antagonize pathogens by competition for root niches or by producing allelochemicals, such as siderophores, antibiotics, biocidal, lytic enzymes, and detoxification enzymes, or by interbacterial antagonism via the type VI secretion system (T6SS) [15,18-20]. The secretion system is a particular kind of molecular weapon that delivers antimicrobial peptide in the periplasm or cytoplasm of a recipient bacterium [21,22]. For example, NADase effector family and iron chelator pyoverdine are identified as antimicrobial peptides mediating antagonism via T6SS, respectively, in Pseudomonas protegens and Pseudomonas taiwanensis [20,23]. Different antibiotic compounds have been isolated from 
Pseudomonas, Bacillus, Paenibacillus, Streptomyces, and Stenotrophomonas spp. (among others [24-28]). These compounds are produced by bacteria in a specific metabolic status that is influenced by nutrient availability, $\mathrm{pH}$, temperature, and genetic stability/instability of the bacteria [29]. Furthermore, biotic conditions, plant growth, development, genotype, and presence of competing species can influence antibiotic biosynthesis [18-30]. BCAs can also protect plants indirectly by inducing the host defense pathways. This phenomenon is called induced systemic resistance (ISR) and confers an enhanced defensive capacity to the plant (reviewed in [31]). The plant response leads to cell wall reinforcement, production of antimicrobial phytoalexins, and synthesis of pathogenesis-related proteins (PR). Interestingly, an enhanced plant capacity to express defense responses occurs only upon challenge inoculation with a pathogen in a mechanism known as 'priming' [32]. Thus, in primed plants, defense responses are not activated directly, but are accelerated upon pathogen or insect attack, avoiding fitness costs in the absence of challenge.

BCAs have been studied for their ability to control or lessen plant pathogens, but little is known about their impact on human health and the environment. As an example, Bacillus species antagonize pathogens via the production of secondary metabolites, such as lipopeptides [33,34]. The toxicity of these metabolites has just started to be tested by in vivo assays (i.e., zebrafish model), showing low toxicity to aquatic species in the case of bacillomycin DC isolated from Bacillus amyloliquefaciens [35]. Since the regulations of the European Union do not define a specific and exclusive legislative/legal framework for such beneficial microorganisms, they can be registered either as plant protection products or as biofertilizers, phytostimulators, and biopesticides according to national law (Table 1). The registration as biofertilizers, phytostimulators, and biopesticides, instead of BCAs, greatly reduces the set of toxicity tests normally required for plant protection agrochemicals [3-6]. As emphasized by Yakin and colleagues [3], the lack of a legislative/legal framework opens topical questions, such as: Which is the best category for cultures of living microorganisms? Which standards of proof of efficacy and safety are appropriate to both stimulate the development of these products and safeguard human and environmental health?

\section{Plant Microbiome: A Fascinating Source of BCAs}

With the first results of The Human Genome Project [36], it was immediately clear that humans are composed of a combination of human cells and microorganisms, and that this intimate relationship plays a role in the human physiology and health state [37-39]. This idea was translated into the plant kingdom: the Plant Microbiome has been defined not only as a group of microbes associated with a plant but also their 'crosstalk' with plant genome and proteome [9,40] (Table 1). Plants teem with microbes associated with the rhizosphere, phyllosphere, endosphere, and with those that adhere to external surfaces. Interestingly, plant microbiomes are structured and form complexes that are interconnected as a network. Inside this system, key taxa have a role in plant fitness, soil fertility, nutrient uptake, plant function, productivity, trait expression (phenotype), environmental plasticity, and health $[9,40]$. This innovative concept of a plant as a supraorganism is, in some way, responsible for the development of environmentally friendly approaches, such as BCAs, to control plant disease and to increase plant productivity [41]. Among BCAs, the endophytes are certainly the most promising group, since they are microorganisms that colonize internal plant tissues for all, or part, of their lifetime, thus being strictly part of the plant microbiome.

In early works, endophytes were isolated on growth culture media after surface disinfection of different plant tissues. Methods for their isolation have been reviewed extensively [42,43]. Afterwards, the development of cultivation-independent fingerprinting molecular methods based on the $16 \mathrm{~S}$ rRNA gene allowed a more specific and detailed description of the microbial diversity in complex communities. Nevertheless, our understanding of microbiota complexity has been achieved mainly through the use of 'next-generation' and now 'third-generation' technologies (among others [8,44-46]). These technologies have been used not only to investigate the microbiota composition but also its relationships with the host and the environment [47-51]. Nonetheless, the effect of BCA treatment on 
endophytic bacterial community composition and activity has been poorly investigated. Hardoim and colleagues [8] have given a comprehensive overview of prokaryotic and eukaryotic endophytes reported in the literature. Despite the extensive amount of sequences analyzed, the major part of endophytes reported belongs to four phyla: Proteobacteria, Actinobacteria, Firmicutes, and Bacteroidetes. Most of the prokaryotic endophytes could be assigned to the Gammaproteobacteria $(26 \%)$ that are largely represented by a few genera: Pseudomonas, Enterobacter, Pantoea, Stenotrophomonas, Acinetobacter, and Serratia. A similar scenario has also been depicted for eukaryotic endophytes which belong mainly to the Glomeromycota (40\%), Ascomycota (31\%), Basidiomycota (20\%), Zygomycota $(0.1 \%)$, and unidentified phyla $(8 \%)$.

Microbiota composition is influenced by different parameters, such as plant genotype and seasonality. Plant genotype, growth stage and physiological status, type of plant tissue, environmental conditions, and agricultural practices also determine endophytic colonization and endosphere community structures (among others [52-56]). Furthermore, metagenomic approaches and comparative genomic analyses allow the identification of intrinsic bacterial traits important for host colonization and for the endophytic lifestyle $[8,57,58]$. In particular, Hardoim et al. [8] highlighted that endophytic bacteria share genes related to motility and chemotaxis, detoxification, and stress-related enzymes, transporters, and secretion systems. As an example, type IV secretion systems and conjugal DNA-protein transfer secretion systems were detected more prominently among endophytes than among rhizosphere bacteria and phytopathogens. These types of secretion systems are involved in host colonization and conjugation of DNA $[59,60]$.

In the last decade, bacteria host colonization process has been extensively reviewed and three main steps were identified: adhesion, penetration, and establishment [8,61-63]. Root colonization is strictly linked to root exudation [64]. These exudates are rich in carbohydrates, amino acids, and organic acids that are attractive nutrient sources for bacteria [65]. Microorganisms are chemoattracted by the exudates, allowing them to colonize roots. In turn, the microbiome influences root exudates [66]. By the use of microscopic tools, such as immunomarkers and fluorescence in situ hybridization [67], bacteria have been visualized at an early stage of infection as single cells attached to the root surface, and subsequently as doublets on the rhizodermis, forming a string of bacteria [63,68]. Once inside the plant, endophytic bacteria remain localized in a specific tissue, such as the root cortex, or colonize the plant systematically by transport or active migration through the conducting elements or the apoplast $[69,70]$ (Figure 1). The different mechanisms of distribution might be due to interactions with other bacteria or to the different requirements of each microorganism, allowing them to inhabit different niches, represented by tissues and, more specifically, by the intercellular spaces within each tissue [71]. Furthermore, comparative genome analyses highlighted the presence of genes involved in plant adhesion and penetration, such as hemagglutinin genes, curli fiber genes, and genes related to plant polymer degradation enzymes [72]. Not all bacteria that reach the rhizosphere are competent to become an endophyte. In fact, the key step to becoming a true endophyte is the so-called 'establishment', that requires a stable relationship with the host which has to recognize and communicate with the microbiota, and vice versa [73]. It seems that at the beginning, endophytes are recognized as alien organisms, inducing microbe-associated molecular patterns (MAMPs)-triggered immunity (MTI) $[74,75]$. Subsequently, they are able to secrete effector proteins that suppress plant MTI responses in order to carry on the colonization process [75]. 

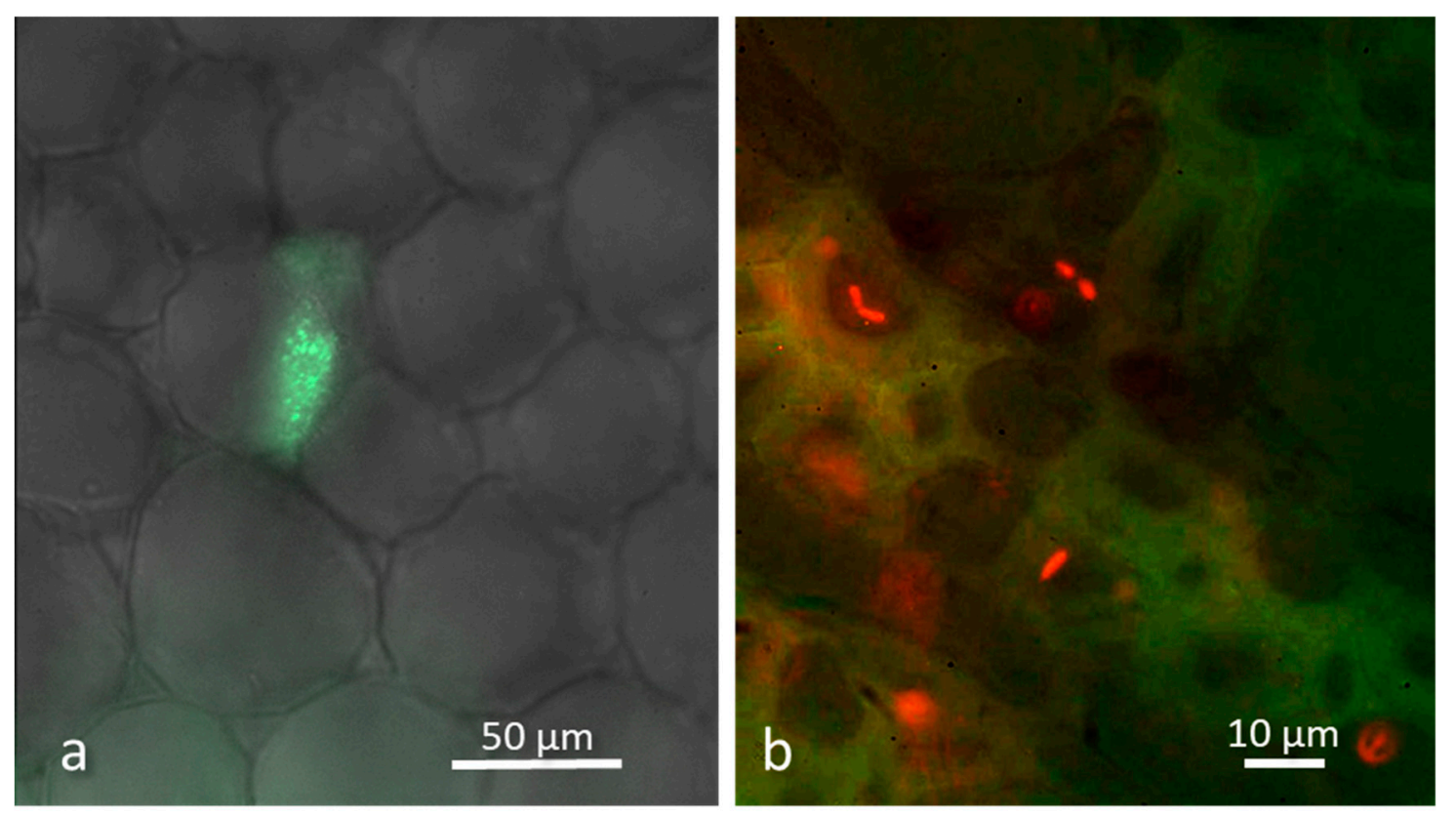

Figure 1. Confocal microscopy images of experimentally inoculated plants showing the ability of endophytic bacteria to inhabit a new host (a) Burkholderia sp. isolated from grapevine leaf tissues [76] and transformed with green fluorescent protein is able to sustain bacterial cell division in periwinkle parenchyma stem cells. (b) Pantoea agglomerans isolated from orchids and transformed with red fluorescent protein [77] has been inoculated via root absorption in apple plantlets: bacterial cells are visible in the upper leaves after two weeks from inoculation, demonstrating the ability to stably colonize a different host.

\section{Human and Animal Pathogens Associated with Plants: Simple Contamination or Survival/Spreading Strategies}

Microbiota associated with plants, including bacteria and fungi, have been extensively studied in order to find new microorganisms suitable for plant protection, growth promotion, industrial and medical applications, pollution control, and phytoremediation [78]. Among the numerous studies on this research topic, only a few pointed out that plants can harbor some human and animal pathogens (HAP) [46,62,79-81]. For a long time, the scientific community believed that human and plant pathogenic bacteria reside in separate hosts, interacting with them in a specific way as a result of coevolution [79]. However, recent studies have begun to show that many plant pathogens have the ability to colonize other hosts outside of the plant kingdom, including insects, animals, and humans [82,83]. A clear example of cross-kingdom host jumps is Agrobacterium tumefaciens. A. tumefaciens was first characterized as the etiological agent of crown gall in rosaceous susceptible genotype [84] and later as a human pathogen [85]. A. tumefaciens is able also to transfer DNA not only into plants, but into fungal and human genomes, revealing the ability to infect different hosts belonging to different kingdoms [86,87].

The genera Pantoea and Burkholderia have been recognized as plant-associated bacteria inducing plant diseases, growth promotion, and/or plant protection depending on the agroecosystem [88]. Despite these microbe-plant interactions, some species of Pantoea and Burkholderia infect humans, causing septicemia, chronic granulomatous disease, melioidosis, arthritis, and urinary infections in immunocompromised humans [79]. The Burkholderia genus includes over 60 species which have been found in a variety of ecological niches, ranging from hospitals to humid environments (among others $[89,90])$. The genus Burkholderia has gained considerable importance owing to its potential in biotechnology applications [88]. Due to its pathogenicity in humans and animals, great efforts have been made to unambiguously discriminate plant pathogenic from non-pathogenic strains, including multilocus sequence analyses and comparative genome analyses [90-92]. Based on phylogenetic 
analyses, the scientific community has recently discussed the possibility of dividing this genus into at least two large clusters, including the cluster of plant or animal/human pathogens and the cluster of plant-associated species [89,90]. Interestingly, Estrada-de los Santos and colleagues [93] described an intermediate cluster between the abovementioned groups. This evidence, in association with the ability of bacteria to exchange genes and to evolve rapidly, highlights the need to deepen our knowledge about the plant-associated Burkholderia strains and their potential for pathogenicity in animals and humans, and to understand whether gene exchange occurs between the symbiotic and pathogenic Burkholderia species. To date, the genetic features characterizing these helpful microorganisms versus the pathogenic ones are not clearly identified and the topic is controversial. It seems that the behavior of the different bacteria is related to gene expression, rather than to the presence or absence of specific genes [94,95].

The plant environment is also a niche for 'true' human and animal pathogens (HAPs), such as Salmonella enterica serovar Typhimurium and Escherichia coli O157:H7, as well as for pathogens that cause diseases in debilitated or immune-compromised humans. Over the past two decades, these so-called opportunistic or facultative human pathogens have had an increasing impact on human health [96,97]. Opportunistic HAPs belonging to different genera, such as Enterobacter, Salmonella, Pantoea, Serratia, Burkholderia, Klebsiella, Clostridium, and Staphylococcus were found in the rhizosphere and associated with different plant organs [46,61,79,98-100]. The occurrence of HAPs in the rhizosphere has been ascribed to several factors, including the nutrient-rich environment, protection from UV radiation, and the availability of water films for dispersal and to prevent desiccation [61,96,101].

The presence of HAPs in plants and outbreaks of foodborne illnesses open new questions about HAP ecology and about the role of plants in the infection cycle [102]. The Enterobacteriaceae family and, especially, the genera Salmonella and Escherichia, have been extensively studied due to the evidence that they cause major foodborne illnesses. A typical example is verocytotoxigenic E. coli (VTEC), which is a foodborne pathogen that can cause serious diseases ranging from hemorrhagic colitis to life-threatening hemolytic uremic syndrome (HUS) and central nervous system damage [103]. Although most cases had been previously associated with contamination of meat, milk products, and eggs, in recent years, fresh fruits and vegetables have been increasingly identified as sources of infection (CDC, Centers of Disease and Control Prevention). Several multistate outbreaks of E. coli serotype infections have been reported by both CDC and Food and Drug Administration (FDA) as having arisen from fresh vegetables. Plant contamination by HAPs can occur at different steps from the agricultural environment to the table. HAPs can contaminate vegetables both pre- and post-harvest through irrigation water, farm workers with limited means of proper sanitation, fertilization with slurry, and manure and fecal contamination in the farm by animals [13,104-106]. Furthermore, during the post-harvest step, HAPs can contaminate plants during carriage, processing, or packaging [104], and it has also been demonstrated that HAPs can escape post-harvest treatments to control plant pathogens $[107,108]$.

Indeed, it has been shown that these so-called contaminations are only a first step in the plant colonization, possibly facilitating the transmission of HAP strains from the field via the food production chain to the consumer with severe impacts on the health of animals and human beings [109]. In this view, plants are recognized as vectors of human pathogens causing phytonoses, a new term for defining the new group of diseases caused by human pathogens, viz., E. coli and S. enterica, that are transmitted via consumption of fresh produce [12,13] (Table 1).

The HAP colonization process of a plant is quite similar to plant bacterial colonization, including adhesion, invasion, and establishment [62,110]. The internalization and survival of bacteria in plants represent a food safety threat in crop production, as internalized bacteria cannot be removed by standard sanitation practices, although treatments such as irradiation, ultrasound, and cold plasma can be effective [111-113]. It has been demonstrated that E. coli O157:H7 can enter in the apoplast of lettuce and spinach from roots and leaves, invade plants, and survive for over 20 days [114,115]. These data, in association with the ability to form biofilm, led to the consideration of these parameters as food risk markers. 


\section{Bacteria Can Overcome Kingdom Barriers}

As mentioned above, bacteria host colonization occurs in three main steps: adhesion, penetration, and establishment. Van Baarlen and colleagues [87] highlighted the most important requirements for establishing a pathogenic relationship. These are mainly based on: (i) proximity between microorganism and host, (ii) host ability to act as substrate, (iii) molecular components secreted by bacteria, and (iv) ability to suppress or avoid host immune responses. Despite fundamental differences, the innate immune systems in different eukaryotic kingdoms share a number of common features. These include the structure of molecules involved in microbial recognition; the signaling pathways mediated by mitogen-associated protein kinase; the presence of reactive oxygen species and antimicrobial peptides and proteins [87]. Microbial recognition can occur through so-called microbial or pathogen-associated molecular patterns (MAMPs/PAMPs), which include different types of molecules, such as the lipopolysaccharides of Gram-negative bacteria and the peptidoglycans of Gram-positive bacteria, as well as bacterial flagellin, microbial DNA, and fungal cell wall constituents [31,116]. Moreover, plant-pathogen recognition is mediated by effector molecules injected or secreted into the host cells by secretion systems. Some systems secrete a variety of substrates, while others are only found in a small number of bacterial species and/or are specific to one or few types of proteins [117]. In plants and animals, MAMPs and effectors are recognized by both cell surface receptors [118] and intracellular receptors of the NLR (nucleotide-binding domain (NBD) and leucine-rich repeat (LRR)) superfamily [119-121]. Microbial recognition mechanisms by plants and animals and their NLR architecture overlap, and it is now possible to discern important key trans-kingdom principles of NLR-dependent immune function [87]. For example, S. enterica induces MAMP-triggered immunity in Arabidopsis thaliana via flagellin FLS2 recognition [122]. Plants and animals share other similarities in host defense signaling after pathogen perception [123], and one class of antimicrobial peptides comprising the defensins is found to be conserved across kingdoms [124].

Finally, cross-kingdom bacteria should be able to survive and live in the future hosts. Survival upon entering a new host is associated with an innate ability to change the metabolic activity or adapting to (and taking advantage of) host metabolism. S. enterica, Pseudomonas aeruginosa, Burkholderia cepacia, and E. coli are the most deeply investigated cross-kingdom pathogens [105]. S. enterica is mainly transmitted via water, from feces to environment and then to crop [105]. Once it reaches plant tissues, it can persist for significant periods of time as it is able to colonize the mesophyll via stomata openings, wounds, and hydathodes, as shown in arugula and tomato plants $[98,100,125-127]$. S. enterica and other enterobacteria (e.g., E. coli) are able to reprogram the host architecture, suppressing the host immune system via the injection of a cocktail of effector proteins (among others [128-130]). The effector proteins and secretion systems of enterobacteria are known, and their function in human and mouse has been described in depth (reviewed in [131]). Interestingly, it has been shown that these proteins are able to suppress plant defense also in tobacco plants and Arabidopsis thaliana [132,133]. In particular, Salmonella T3SS effectors (Type III secretion system) are essential for both animal pathogenicity and the plant colonization process [132-135]. Recently, Neumann and colleagues [129] demonstrated that the phosphothreonine lyase SpvC attenuates the induction of immunity-related genes, allowing bacteria proliferation in Arabidopsis thaliana. This evidence strongly confirms the idea that plants could be reservoirs or vectors of human pathogens. 


\section{Possible Unfavorable Consequences of the Massive Use of Bacteria as Biocontrol or Biofertilizer Agents}

The concept of the 'pathobiome' has been introduced to define the role of the microbiome in causing pathogenesis, replacing the dogma 'one microbe-one disease' [11,78]. This term was coined based on metagenomic data showing the complexity of the microbial communities associated with the ecological niches inhabited by pathogens. Disease development can be then influenced by variations in host-associated microbial populations, signaling within bacterial communities, and the immune state of the host [136-139]. In other words, pathogenicity is an outcome of host-microbe interactions, thus inextricably linked to the host and microbe characteristics [140]. As a consequence, the separation between beneficial and detrimental microorganisms is not that clear-cut, due to the fact that horizontal gene transfers (HGTs) may confer virulence traits to harmless bacteria [141,142].

As discussed in the previous paragraphs, most BCAs are close relatives of HAPs. Moreover, comparative genome analyses have shown that endophytic bacteria, often recommended as BCAs, share genome structures and distributions of virulence genes with pathogenic bacteria $[92,94]$. This evidence suggests the ability of these bacteria to change their lifestyle according to the ecological niche. For example, the genus Paenibacillus, a promising genus for biocontrol, exhibits extensive environmental adaptability and can populate various ecological niches [28]. Comparative genome analyses of Paenibacillus spp. revealed that this capacity is related to a highly diverse gene repertoire and to the HGT trend [143].

From this perspective, the massive use of bacterial BCAs to control pathogens or as biofertilizer could affect disease development and increase the possibility of new pathogen emergence by altering the host-associated microbiome and/or the host immune system. Moreover, the potential direct pathogenicity of putative BCAs to human health has been often underinvestigated, even if some of them (e.g., Burkholderia spp., Paenibacillus spp., and Pseudomonas spp.) have been reported as opportunistic human or animal pathogens, or are known to produce secondary metabolites potentially toxic for humans and animals (Figure 2). For example, Paenibacillus polymyxa is reported in the literature as a prominent biofertilizer or biocontrol agent [144], even if this species produces cyclic lipodepsipeptide fusaricidins that are toxic to mitochondria and induce apoptosis in mammalian cells [145].

This evidence, in combination with the outbreaks of human infections associated with the consumption of raw fruits and vegetables, opens new questions regarding the role of plants in the human pathogen infection cycle, or if a biological control could alter the endophytic bacterial community, leading to the generation of new potential human pathogens. 


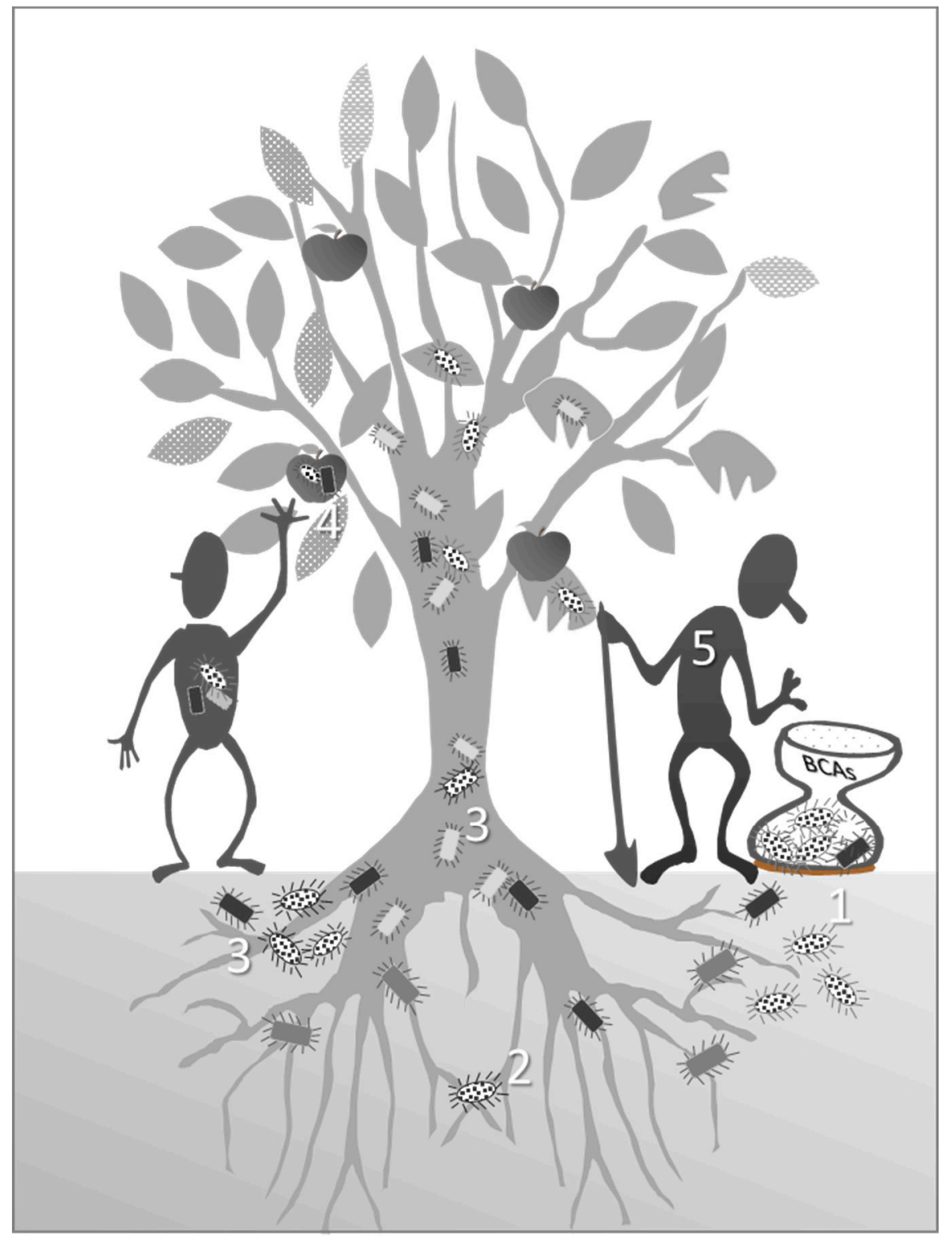

Figure 2. Schematic representation of a potential scenario following plant disease/growth biocontrol: (1) Biocontrol agents (BCAs, in dotted white), differently formulated, are spread into the soil; (2) they interact with soil and plant microbiomes (in gray and light gray, respectively) improving plant health and fitness; (3) BCAs can also interact with human pathogens (in black) harbored by plants, possibly leading to horizontal gene transfer (i.e., resistance to antibiotics); (4) these bacteria could migrate through the plant up to the edible parts, whose consumption may lead to severe diseases, such as septicemia and urinary infection; (5) finally, BCAs potentially pathogens for humans and animals (in black) can contaminate the farm workers or the post-harvest process, entering into the food chain.

\section{Conclusions}

Bacteria are essential components of human, animal, and plant health, and important sources of new molecules suitable for industrial, medicine, and agricultural applications. Nevertheless, some of the endophytic bacteria and fungi used in biocontrol or biofertilization strategies are indeed true or opportunistic human and animal pathogens, or carry human virulence factors in their genome. Thus, their massive spreading in the soil and in the environment, with scarce or no knowledge of their interactions with plants and with the phyllosphere and rhizosphere microbiomes, may lead to unpredictable long-term consequences. Although biocontrol is a promising approach to controlling plant pathogens, it is important to re-think the assumption 'isolation from plant is safe', taking into 
account the possible direct or indirect effects on human health and the environment, which have so far been unappreciated. Nowadays, the omics technologies can hopefully contribute to deeply understanding the new bacteria-plant-animal interactions and, thus, their impact on agroecosystems and human health. Omics technologies can contribute to increase this knowledge constituting the starting point for testing predictive hypotheses on microbial pathogenicity in model systems.

Funding: This research received no external funding.

Conflicts of Interest: The authors declare no conflict of interest.

\section{References}

1. Flint, M.L.; Dreistad, S.H. Natural Enemies Handbook: The Illustrated Guide to Biological Pest Control; University of California Press: Oakland, CA, USA, 1998.

2. Francis, M.; Holsters, M.; Vereecke, D. The Gram-positive side of plant-microbe interactions. Environ. Microbiol. 2009, 12, 1-12. [CrossRef] [PubMed]

3. Yakhin, O.I.; Lubyanov, A.A.; Yakhin, I.A.; Brown, P.H. Biostimulants in Plant Science: A Global Perspective. Front. Plant Sci. 2017, 7, 2049. [CrossRef] [PubMed]

4. Glare, T.; Caradus, J.; Gelernter, W.; Jackson, T.; Keyhani, N.; Köhl, J.; Marrone, P.; Reardon, R.C.; Podgwaite, J.; Zerillo, R. Have biopesticides come of age? Trends Biotechnol. 2012, 30, 250-258. [CrossRef] [PubMed]

5. Du Jardin, P. Plant biostimulants: Definition, concept, main categories and regulation. Sci. Hortic. 2015, 196, 3-14. [CrossRef]

6. Martínez-Viveros, O.; Jorquera, M.A.; Crowley, D.E.; Gajardo, G.; Mora, M.L. Mechanisms and practical considerations involved in plant growth promotion by rhizobacteria. J. Soil Sci. Plant Nutr. 2010, 10, 293-319. [CrossRef]

7. Pirofski, L.A.; Casadevall, A. Q\&A: What is a pathogen? A question that begs the point. BMC Biol. 2012, 10, 6. [CrossRef]

8. Hardoim, P.R.; van Overbeek, L.S.; Berg, G.; Pirttilä, A.M.; Compant, S.; Campisano, A.; Döring, M.; Sessitsch, A. The Hidden world within plants: Ecological and evolutionary considerations for defining functioning of microbial endophytes. Microbiol. Mol. Biol. Rev. 2015, 79, 293-320. [CrossRef] [PubMed]

9. Rout, M.E. The Plant Microbiome. In Advances in Botanical Research; Paterson, A.H., Ed.; Elsevier Ltd.: Amsterdam, The Netherlands, 2014; Volume 69, pp. 280-302.

10. Chow, J.; Tang, H.; Mazmanian, S.K. Pathobionts of the gastrointestinal microbiota and inflammatory disease. Curr. Opin. Immunol. 2011, 23, 473-480. [CrossRef] [PubMed]

11. Vayssier-Taussat, M.; Albina, E.; Citti, C.; Cosson, J.F.; Jacques, M.-A.; Lebrun, M.-H.; Le Loir, Y.; Ogliastro, M.; Petit, M.A.; Roumagnac, P.; et al. Shifting the paradigm from pathogens to pathobiome: New concepts in the light of meta-omics. Front. Cell. Infect. Microbiol. 2014, 4, 29. [CrossRef] [PubMed]

12. Van der Riet, F.D. Diseases of plants transmissible between plants and man (phytonoses) exist. Med. Hypotheses 1997, 49, 359-361.

13. Van Overbeek, L.S.; van Doorn, J.; Wicher, J.H.; Amerongen, A.; van Roermund, H.J.W.; Willemsen, P.T.J. The arable ecosystem as battle ground for emergence of new human pathogens. Front. Microbiol. 2014, 4, 104. [CrossRef]

14. Bais, H.P.; Park, S.W.; Weir, T.L.; Callaway, R.M.; Vivanco, J.M. How plants communicate using the underground information superhighway. Trends Plant. Sci. 2004, 9, 26-32. [CrossRef] [PubMed]

15. Lugtenberg, B.; Kamilova, F. Plant-growth-promoting rhizobacteria. Annu. Rev. Microbiol. 2009, 63, 541-556. [CrossRef] [PubMed]

16. Ellis, J.G. Can microbiome studies lead to effective biocontrol of plant disease? Mol. Plant Microbe Interact. 2017, 30, 190-193. [CrossRef] [PubMed]

17. Bashan, Y.; de-Bashan, L.E.; Prabhu, S.R.; Hernandez, J.P. Advances in plant growth-promoting bacterial inoculant technology: Formulations and practical perspectives (1998-2013). Plant Soil 2014, 378, 1-33. [CrossRef]

18. O'Brien, P.A. Biological control of plant diseases. Australas. Plant Pathol. 2017, 46, 293-304. [CrossRef]

19. Bernal, P.; Allsopp, L.P.; Filloux, A.; Llamas, M.A. The Pseudomonas putida T6SS is a plant warden against phytopathogens. ISME J. 2017, 11, 972-987. [CrossRef] [PubMed] 
20. Tang, J.; Bullen, N.P.; Ahmad, S.; Whitney, J.C. Diverse NADase effector families mediate interbacterial antagonism via the type VI secretion system. J. Biol. Chem. 2018, 293, 1504-1514. [CrossRef]

21. Vettiger, A.; Basler, M. Type VI secretion system substrates are transferred and reused among sister cells. Cell 2016, 167, 99-110. [CrossRef] [PubMed]

22. Ho, B.T.; Fu, Y.; Dong, T.G.; Mekalanos, J.J. Vibrio cholerae type 6 secretion system effector trafficking in target bacterial cells. Proc. Natl. Acad. Sci. USA 2017, 114, 9427-9432. [CrossRef] [PubMed]

23. Chen, W.J.; Kuo, T.Y.; Hsieh, F.C.; Chen, P.Y.; Wang, C.S.; Shih, Y.L.; Lai, Y.M.; Liu, J.R.; Yang, Y.L.; Shih, M.C. Involvement of type VI secretion system in secretion of iron chelator pyoverdine in Pseudomonas taiwanensis. Sci Rep. 2016, 8, 32950. [CrossRef] [PubMed]

24. Milner, J.L.; Silo-Suh, L.; Lee, J.C.; He, H.Y.; Clardy, J.; Handelsman, J. Production of kanosamine by Bacillus cereus UW85. Appl. Environ. Microbiol. 1996, 62, 3061-3065. [PubMed]

25. Nakayama, T.; Homma, Y.; Hashidoko, Y.; Mizutani, J.; Tahara, S. Possible role of xanthobaccins produced by Stenotrophomonas sp. strain SB-K88 in suppression of sugar beet damping-off disease. Appl. Environ. Microbiol. 1999, 65, 4334-4339. [PubMed]

26. Raaijmakers, J.M.; Vlami, M.; de Souza, J.T. Antibiotic production by bacterial biocontrol agents. Antonie Van Leeuwenhoek 2002, 81, 537. [CrossRef] [PubMed]

27. Stein, T. Bacillus subtilis antibiotics: Structures, syntheses and specific functions. Mol Microbiol. 2005, 56, 845-885. [CrossRef] [PubMed]

28. Grady, E.N.; MacDonald, J.; Liu, L.; Richman, A.; Yuan, Z.-C. Current knowledge and perspectives of Paenibacillus: A review. Microb. Cell Fact. 2016, 15, 203. [CrossRef] [PubMed]

29. Compant, S.; Duffy, B.; Nowak, J.; Clement, C.; Barka, E.A. Use of plant growth-promoting bacteria for biocontrol of plant diseases: Principles, mechanisms of action, and future prospects. Appl. Environ. Microbiol. 2005, 71, 4951-4959. [CrossRef]

30. Tyc, O.; van den Berg, M.; Gerards, S.; van Veen, J.A.; Raaijmakers, J.M.; de Boer, W.; Garbeva, P. Impact of interspecific interactions on antimicrobial activity among soil bacteria. Front. Microbiol. 2014, 5, 567. [CrossRef]

31. Gozzo, F.; Faoro, F. Systemic Acquired Resistance (50 years after discovery): Moving from the lab to the field. J. Agric. Food Chem. 2013, 61, 12473-12491. [CrossRef]

32. Conrath, U.; Beckers, G.J.; Flors, V.; Garcia-Agustin, P.; Jakab, G.; Mauch, F.; Newman, M.A.; Pieterse, C.M.; Poinssot, B.; Pozo, M.J.; et al. Priming: Getting ready for battle. Mol. Plant Microbe Interact. 2006, 19, 1062-1071. [CrossRef]

33. Yuan, J.; Li, B.; Zhang, N.; Waseem, R.; Shen, Q.; Huang, Q. Production of bacillomycin- and macrolactin-type antibiotics by Bacillus amyloliquefaciens NJN-6 for suppressing soilborne plant pathogens. J. Agric. Food Chem. 2012, 60, 2976-2981. [CrossRef] [PubMed]

34. Tanaka, A.; Shihara, H.; Nakajima, H. Isolation of anteiso-C17, iso-C17, iso-C16, and iso-C15 bacillomycin D from Bacillus amyloliquefaciens SD-32 and their antifungal activities against plant pathogens. J. Agric. Food Chem. 2014, 62, 1469-1476. [CrossRef] [PubMed]

35. Jin, P.; Wang, H.; Liu, W.; Fan, Y.; Miao, W. A new cyclic lipopeptide isolated from Bacillus amyloliquefaciens HAB-2 and safety evaluation. Pest. Biochem. Physiol. 2017, 147, 40-45. [CrossRef] [PubMed]

36. Peterson, J.; Garges, S.; Giovanni, M.; McInnes, P.; Wang, L.; Schloss, J.A.; Bonazzi, V.; McEwen, J.E.; Wetterstrand, K.A.; Deal, C. The NIH Human Microbiome Project. Genome Res. 2009, 19, 2317-2323. [CrossRef] [PubMed]

37. Turnbaugh, P.J.; Ley, R.E.; Hamady, M.; Fraiser-Liggett, C.M.; Knight, R.; Gordon, J.I. The human microbiome project: A strategy to understand the microbial components of the human genetic and metabolic landscape and how they contribute to normal physiology and predisposition to disease. Nature 2007, 449, 804-810. [CrossRef] [PubMed]

38. Greenblum, S.; Turnbaugh, P.J.; Borenstein, E. Metagenomic systems biology of the human gut microbiome reveals topological shifts azssociated with obesity and inflammatory bowel disease. Proc. Natl. Acad. Sci. USA 2012, 109, 594-599. [CrossRef] [PubMed]

39. Koeth, R.A.; Wang, Z.; Levison, B.S.; Buffa, J.A.; Org, E.; Sheehy, B.T.; Britt, E.B.; Fu, X.; Wu, Y.; Li, L.; et al. Intestinal microbiota metabolism of L-carnitine, a nutrient in red meat, promotes atherosclerosis. Nat. Med. 2013, 19, 576-585. [CrossRef] 
40. Van der Heijden, M.G.A.; Hartmann, M. Networking in the Plant Microbiome. PLoS Biol. 2016, 14, e1002378. [CrossRef]

41. Berg, G.; Grube, M.; Schloter, M.; Smalla, K. Unraveling the plant microbiome: Looking back and future perspectives. Front. Microbiol. 2014, 5, 148. [CrossRef]

42. Hallmann, J.; QuadtHallmann, A.; Mahaffee, W.F.; Kloepper, J.W. Bacterial endophytes in agricultural crops. Can. J. Microbiol. 1997, 43, 895-914. [CrossRef]

43. Eevers, N.; Gielen, M.; Sánchez-López, A.; Jaspers, S.; White, C.; Vangronsveld, J.; Weyens, N. Optimization of isolation and cultivation of bacterial endophytes through addition of plant extract to nutrient media. Microb. Biotechnol. 2015, 8, 707-715. [CrossRef]

44. Sessitsch, A.; Hardoim, P.; Döring, J.; Weilharter, A.; Krause, A.; Woyke, T.; Mitter, B.; Hauberg-Lotte, L.; Friedrich, F.; Rahalkar, M.; et al. Functional characteristics of an endophyte community colonizing rice roots as revealed by metagenomics analysis. Mol. Plant Microbe Interact. 2012, 25, 28-36. [CrossRef]

45. Knief, C. Analysis of plant microbe interactions in the era of next generation sequencing technologies. Front. Plant Sci. 2014, 5, 216. [CrossRef]

46. Yousaf, S.; Bulgari, D.; Bergna, A.; Pancher, M.; Quaglino, F.; Casati, P.; Campisano, A. Pyrosequencing detects human and animal pathogenic taxa in the grapevine endosphere. Front. Microbiol. 2014, 5, 327. [CrossRef] [PubMed]

47. Jansson, J.K.; Neufeld, J.D.; Moran, M.A.; Gilbert, J.A. Omics for understanding microbial functional dynamics. Environ. Microbiol. 2012, 14, 1-3. [CrossRef] [PubMed]

48. Vorholt, J.A. Microbial life in the phyllosphere. Nat. Rev. Microbiol. 2012, 10, 828-840. [CrossRef] [PubMed]

49. Berg, G.; Zachow, C.; Müller, H.; Philipps, J.; Tilcher, R. Next generation bio-products sowing the seeds of success for sustainable agriculture. Agronomy 2013, 3, 648-656. [CrossRef]

50. Finkel, O.M.; Delmont, T.O.; Post, A.F.; Belkin, S. Metagenomic signatures of bacterial adaptation to life in the phyllosphere of a salt-secreting desert tree. Appl. Environ. Microbiol. 2016, 82, 2854-2861. [CrossRef]

51. Proença, D.N.; Francisco, R.; Kublik, S.; Schöler, A.; Vestergaard, G.; Schloter, M.; Morais, P.V. The microbiome of endophytic, wood colonizing bacteria from pine trees as affected by pine wilt disease. Sci. Rep. 2017, 7, 4205. [CrossRef]

52. Hallmann, J.; Berg, G. Spectrum and population dynamics of bacterial root endophytes. In Microbial Root Endophytes; Schulz, B.J.E., Boyle, C.J.C., Sieber, T.N., Eds.; Springer: Dordercht, The Netherlands, 2006; pp. 15-31.

53. Van Overbeek, L.S.; van Elsas, J.D. Effects of plant genotype and growth stage on the structure of bacterial communities associated with potato (Solanum tuberosum L.). FEMS Microbiol. Ecol. 2008, 64, 283-296. [CrossRef]

54. Bulgari, D.; Bozkurt, A.I.; Casati, P.; Caglayan, K.; Quaglino, F.; Bianco, P.A. Endophytic bacterial community living in roots of healthy and 'Candidatus Phytoplasma mali'-infected apple (Malus domestica, Borkh.) trees. Antonie Van Leeuwenhoek 2012, 102, 677-687. [CrossRef]

55. Bulgari, D.; Casati, P.; Quaglino, F.; Bianco, P.A. Endophytic bacterial community of grapevine leaves influenced by sampling date and phytoplasma infection process. BMC Microbiol. 2014, 14, 198. [CrossRef]

56. Bulgarelli, D.; Rott, M.; Schlaeppi, K.; van Themaat, E.V.L.; Ahmadinejad, N.; Assenza, F.; Rauf, P.; Huettel, B.; Reinhardt, R.; Schmelzer, E.; et al. Revealing structure and assembly cues for Arabidopsis root-inhabiting bacterial microbiota. Nature 2012, 488, 91-95. [CrossRef]

57. Ryan, R.P.; Germaine, K.; Franks, A.; Ryan, D.J.; Dowling, D.N. Bacterial endophytes: Recent developments and applications. FEMS Microbiol. Lett. 2008, 278, 1-9. [CrossRef]

58. Bulgarelli, D.; Schlaeppi, K.; Spaepen, S.; van Themaat, E.V.L.; Schulze-Lefert, P. Structure and functions of the bacterial microbiota of plants. Annu. Rev. Plant Biol. 2013, 64, 807-838. [CrossRef]

59. Pitzschke, A.; Hirt, H. New insights into an old story: Agrobacterium-induced tumour formation in plants by plant transformation. EMBO J. 2010, 29, 1021-1032. [CrossRef]

60. Salomon, D.; Kinch, L.N.; Trudgian, D.C.; Guo, X.; Klimko, J.A.; Grishin, N.V.; Mirzaei, H.; Orth, K. Marker for type VI secretion system effectors. Proc. Natl. Acad. Sci. USA 2014, 111, 9271-9276. [CrossRef]

61. Tyler, H.L.; Triplett, E.W. Plants as a Habitat for beneficial and/or human pathogenic bacteria. Annu. Rev. Phytopathol. 2008, 46, 53-73. [CrossRef]

62. Holden, N.; Pritchard, L.; Toth, I. Colonization out with the colon: Plants as an alternative environmental reservoir for human pathogenic Enterobacteria. FEMS Microbiol. Rev. 2009, 33, 689-703. [CrossRef] 
63. Compant, S.; Clément, C.; Sessitsch, A. Plant growth-promoting bacteria in the rhizo- and endosphere of plants: Their role, colonization, mechanisms involved and prospects for utilization. Soil Biol. Biochem. 2010, 42, 669-678. [CrossRef]

64. Lugtenberg, B.J.J.; Dekkers, L.C. What makes Pseudomonas bacteria rhizosphere competent? Environ. Microbiol. 1999, 1, 9-13. [CrossRef]

65. Walker, L.R.; del Moral, R. Primary Succession and Ecosystem Rehabilitation; Cambridge University Press: New York, NY, USA, 2003.

66. Turner, T.R.; James, E.K.; Poole, P.S. The plant microbiome. Genome Biol. 2013, 14, 209. [CrossRef]

67. Bulgari, D.; Casati, P.; Faoro, F. Fluorescence in situ hybridization for phytoplasma and endophytic bacteria localization in plant tissues. J. Microbiol. Methods 2011, 87, 220-223. [CrossRef]

68. Hansen, M.L.; Kregelund, L.; Nybroe, O.; Sørensen, J. Early colonization of barley roots by Pseudomonas fluorescens studied by immunofluorescence technique and confocal laser scanning microscopy. FEMS Microbiol. Ecol. 1997, 23, 353-360. [CrossRef]

69. Hurek, T.; Reinhold-Hurek, B.; van Montagu, M.; Kellemberg, E. Root colonization and systemic spreeding of Azoarcus sp. Strain BH72 in grasses. J. Bacteriol. 1994, 176, 1913-1923. [CrossRef]

70. Mahaffee, W.F.; Kloepper, J.W.; van Vurdee, J.W.L.; van der Wolf, J.M.; van den Brink, M. Endophytic colonization of Phaseolus vulgaris by Pseudomonas fluorescent strain $89 \mathrm{~B}-27$ and Enterobacter asburiae strain JM22. In Improve Plant Productivity in Rhizosphere Bacteria; Ryder, M.H., Stephens, P.M., Bowen, G.D., Eds.; CSIRO Division of Soils: Melbourne, Australia, 1994; p. 180.

71. Di Fiore, S.; Del Gallo, M. Endophytic Bacteria: Their Possible Role in the Host Plant. In Azospirillum VI and Related Microorganisms; Fendrik, I., Del Gallo, M., Vanderleyden, J., de Zamaroczy, M., Eds.; NATO ASI Series (Series G: Ecological Sciences); Springer: Berlin/Heidelberg, Germany, 1995; Volume 37.

72. Mitter, B.; Petric, A.; Shin, M.W.; Chain, P.S.G.; Hauberg-Lotte, L.; Reinhold-Hurek, B.; Nowak, J.; Sessitsch, A. Comparative genome analysis of Burkholderia phytofirmans PsJN reveals a wide spectrum of endophytic lifestyles based on interaction strategies with host plants. Front. Plant Sci. 2013, 4, 120. [CrossRef]

73. Hardoim, P.R.; van Overbeek, L.S.; van Elsas, J.D. Properties of bacterial endophytes and their proposed role in plant growth. Trends Microbiol. 2008, 16, 463-471. [CrossRef]

74. Millet, Y.A.; Danna, C.H.; Clay, N.K.; Songnuan, W.; Simon, M.D.; Werck-Reichhart, D.; Ausubela, F.M. Innate immune responses activated in Arabidopsis roots by Microbe-Associated Molecular Patterns. Plant Cell 2010, 22, 973-990. [CrossRef]

75. Zamioudis, C.; Pieterse, C.M.J. Modulation of host immunity by beneficial microbes. Mol. Plant Microbe Interact. 2012, 25, 139-150. [CrossRef]

76. Bulgari, D.; Casati, P.; Brusetti, L.; Quaglino, F.; Brasca, M.; Daffonchio, D.; Bianco, P.A. Endophytic bacterial diversit y in grapevine (Vitis vinifera L.) leaves described by $16 \mathrm{~S}$ rRNA gene sequence analysis and Length Heterogeneity-PCR. J. Microbiol. 2009, 47, 393-401. [CrossRef]

77. Tondello, A. Endophyte Watching: Combining Molecular and Microscopy Approaches to Isolate, Identify, Tag, and Monitor Fungi and Bacteria Inside Plants. Ph.D. Thesis, Università di Padova, Padua, Italy, 2009.

78. Ryan, E.T. The intestinal pathobiome: Its reality and consequences among infants and young children in resource-limited settings. J. Infect. Dis. 2013, 208, 1732-1733. [CrossRef]

79. Kirzinger, M.W.B.; Nadarasah, G.; Stavrinides, J. Insights into Cross-Kingdom Plant Pathogenic Bacteria. Genes 2011, 2, 980-997. [CrossRef]

80. Campisano, A.; Ometto, L.; Compant, S.; Pancher, M.; Antonielli, L.; Yousaf, S.; Varotto, C.; Anfora, G.; Pertot, I.; Sessitsch, A.; et al. Interkingdom transfer of the acne-causing agent, Propionibacterium acnes, from human to grapevine. Mol. Biol. Evol. 2014, 31, 1059-1065. [CrossRef]

81. Nithya, A.; Babu, S. Prevalence of plant beneficial and human pathogenic bacteria isolated from salad vegetables in India. BMC Microbiol. 2017, 17, 64. [CrossRef]

82. Sharma, K.; Goss, E.M.; Dickstein, E.R.; Smith, M.; Southwick, F.; van Bruggen, A.H.C. Exserohilum rostratum: Characterization of a cross-kingdom pathogen. PLoS ONE 2014, 9, e108691. [CrossRef]

83. Van Diepeningen, A.D.; de Hoog, G.S. Challenges in Fusarium, a trans-kingdom pathogen. Mycopathologia 2016, 181, 161-163. [CrossRef]

84. Hayward, A.C.; Waterston, J.M. Agrobacterium Tumefaciens. Descriptions of Pathogenic Fungi and Bacteria; No. 42; Commonwealth Mycological Institute, Kew: Surrey, UK, 1965. 
85. Paphitou, N.I.; Rolston, K.V. Catheter-related bacteremia caused by Agrobacterium radiobacter in a cancer patient: Case report and literature review. Infection 2003, 31, 421-424.

86. Lacroix, B.; Tzfira, T.; Vainstein, A.; Citovsky, V. A case of promiscuity: Agrobacterium's endless hunt for new partners. Trends Genet. 2006, 22, 29-37. [CrossRef]

87. Van Baarlen, P.; van Belkum, A.; Summerbell, R.C.; Crous, P.W.; Thomma, B.P.H.J. Molecular mechanisms of pathogenicity: How do pathogenic microorganisms develop cross-kingdom host jumps? FEMS Microbiol. Rev. 2007, 31, 239-277. [CrossRef]

88. Suárez-Moreno, Z.R.; Caballero-Mellado, J.; Coutinho, B.C.; Mendonça-Previato, L.; James, E.K.; Venturi, V. Common features of environmental and potentially beneficial plant-associated Burkholderia. Microb. Ecol. 2012, 63, 249-266. [CrossRef]

89. Weisskopf, L.; Heller, S.; Eberl, L. Burkholderia species are major inhabitants of white lupin cluster roots. Appl. Environ. Microbiol. 2011, 77, 7715-7720. [CrossRef]

90. Estrada-de los Santos, P.; Vinuesa, P.; Martínez-Aguilar, L.; Hirsch, A.M.; Caballero-Mellado, J. Phylogenetic analysis of Burkholderia species by multilocus sequence analysis. Curr. Microbiol. 2013, 67, 51-60. [CrossRef]

91. Eberl, L.; Vandamme, P. Members of the genus Burkholderia: Good and bad guys [version 1; referees: 3 approved]. F1000 Res. 2016, 5. [CrossRef]

92. Nguyen, T.T.; Lee, H.H.; Park, J.; Park, I.; Seo, Y.S. Computational identification and comparative analysis of secreted and transmembrane proteins in six Burkholderia species. Plant Pathol. J. 2017, 33, 148-162. [CrossRef]

93. Estrada-de los Santos, P.; Rojas-Rojas, F.U.; Tapia-García, E.Y.; Vásquez-Murrieta, M.S.; Hirsch, A.M. To split or not to split: An opinion on dividing the genus Burkholderia. Ann. Microbiol. 2016, 66, 1303-1314. [CrossRef]

94. Lòpez-Fernàndez, S.; Sonego, P.; Moretto, M.; Pancher, M.; Engelen, K.; Pertot, I.; Campisano, A. A Whole-genome comparative analysis of virulence genes unveils similarities and differences between endophytes and other symbiotic bacteria. Front. Microbiol. 2015, 6, 419. [CrossRef]

95. Sheibani-Tezerji, R.; Rattei, T.; Sessitsch, A.; Trognitz, F.; Mitter, B. Transcriptome Profiling of the Endophyte Burkholderia phytofirmans PsJN Indicates Sensing of the Plant Environment and Drought Stress. MBio 2015, 6, e00621-15. [CrossRef]

96. Berg, G.; Eberl, L.; Hartmann, A. The rhizosphere as a reservoir for opportunistic human pathogenic bacteria. Environ. Microbiol. 2005, 7, 1673-1685. [CrossRef]

97. Teplitski, M.; Warriner, K.; Bartz, J.; Schneider, K.R. Untangling metabolic and communication networks: Interactions of enterics with phytobacteria and their implications in produce safety. Trends Microbiol. 2011, 19, 121-127. [CrossRef]

98. Gu, G.; Hu, J.; Cevallos-Cevallos, J.M.; Richardson, S.M.; Bartz, J.A.; van Bruggen, A.H.C. Internal colonization of Salmonella enterica serovar Typhimurium in tomato plants. PLoS ONE 2011, 6, e27340. [CrossRef]

99. Cevallos-Cevallos, J.M.; Gu, G.; Danyluk, M.D.; van Bruggen, A.H.C. Adhesion and splash dispersal of Salmonella enterica Typhimurium on tomato leaflets: Effects of rdar morphotype and trichome density. Int. J. Food Microbiol. 2012, 160, 58-64. [CrossRef] [PubMed]

100. Gu, G.; Cevallos-Cevallos, J.M.; van Bruggen, A.H.C. Ingress of Salmonella enteric Typhimurium into tomato leaves through hydathodes. PLoS ONE 2013, 8, e53470. [CrossRef]

101. Bais, H.P.; Weir, T.L.; Perry, L.G.; Gilroy, S.; Vivanco, M. The role of root exudates in rhizosphere interactions with plant and other organisms. Annu. Rev. Plant Biol. 2006, 57, 233-266. [CrossRef] [PubMed]

102. Franz, E.; van Bruggen, A.H.C. Ecology of E. coli O157:H7 and Salmonella enterica in the primary vegetable production chain. Crit. Rev. Microbiol. 2008, 34, 143-161. [CrossRef] [PubMed]

103. Kaper, J.B.; Nataro, J.P.; Mobley, H.L. Pathogenic Escherichia coli. Nat. Rev. Microbiol. 2004, 2, $123-140$. [CrossRef]

104. Lynch, M.F.; Tauxe, R.V.; Hedberg, C.W. The growing burden of food-borne outbreaks due to contaminated fresh produce: Risks and opportunities. Epidemiol. Infect. 2009, 137, 307-315. [CrossRef] [PubMed]

105. Barak, J.D.; Schroeder, B.K. Interrelationships of food safety and plant pathology: The life cycle of human pathogens on plants. Annu. Rev. Phytopathol. 2012, 50, 241-266. [CrossRef] [PubMed]

106. Chen, Z.; Jiang, X. Microbiological safety of chicken litter or chicken litter-based organic fertilizers: A review. Agriculture 2014, 4, 1-29. [CrossRef] 
107. Seo, K.H.; Frank, J.F. Attachment of Escherichia coli O157:H7 to lettuce leaf surface and bacterial viability in response to chlorine treatment as demonstrated by using confocal scanning laser microscopy. J. Food Prot. 1999, 62, 3-9. [CrossRef]

108. Saldaña, Z.; Sánchez, E.; Xicohtencatl-Cortes, J.; Puente, J.L.; Girón, J.A. Surface structures involved in plant stomata and leaf colonization by shiga-toxigenic Escherichia coli O157:H7. Front. Microbiol. 2011, 2, 119. [CrossRef]

109. Hofmann, A.; Fischer, D.; Hartmann, A.; Schmid, M. Colonization of plants by human pathogenic bacteria in the course of organic vegetable production. Front. Microbiol. 2014, 5, 191. [CrossRef] [PubMed]

110. Melotto, M.; Panchal, S.; Roy, D. Plant innate immunity against human bacterial pathogens. Front. Microbiol. 2014, 5, 411. [CrossRef] [PubMed]

111. Gomes, C.; Da Silva, P.; Moreira, R.G.; Castell-Perez, E.; Ellis, E.A.; Pendleton, M. Understanding E. coli internalization in lettuce leaves for optimization of irradiation treatment. Int. J. Food Microbiol. 2009, 135, 238-247. [CrossRef] [PubMed]

112. Bilek, S.E.; Turantas, F. Decontamination efficiency of high power ultrasound in the fruit and vegetable industry, a review. Int. J. Food Microbiol. 2013, 166, 155-162. [CrossRef] [PubMed]

113. Ziuzin, D.; Han, L.; Cullen, P.J.; Bourke, P. Cold plasma inactivation of internalized bacteria and biofilms for Salmonella enterica serovar Typhimurium, Listeria monocytogenes and Escherichia coli. Int. J. Food Microbiol. 2015, 210, 53-61. [CrossRef]

114. Cooley, M.B.; Miller, W.G.; Mandrell, R.E. Colonization of Arabidopsis thaliana with Salmonella enterica and enterohemorrhagic Escherichia coli O157:H7 and competition by Enterobacter asburiae. Appl. Environ. Microbiol. 2003, 69, 4915-4926. [CrossRef]

115. Wright, K.M.; Crozier, L.; Marshall, J.; Merget, B.; Holmes, A.; Holden, N.J. Differences in internalization and growth of Escherichia coli O157:H7 within the apoplast of edible plants, spinach and lettuce, compared with the model species Nicotiana benthamiana. Microbial Biotechnol. 2017, 10, 555-569. [CrossRef]

116. Girardin, S.E.; Sansonetti, P.J.; Philpott, D.J. Intracellular vs extracellular recognition of pathogens-Common concepts in mammals and flies. Trends Microbiol. 2002, 10, 193-199. [CrossRef]

117. Green, E.; Mecsas, J. Bacterial Secretion Systems: An Overview. In Virulence Mechanisms of Bacterial Pathogens, 5th ed.; Kudva, I., Cornick, N., Plummer, P., Zhang, Q., Nicholson, T., Bannantine, J., Bellaire, B.H., Eds.; ASM Press: Washington, DC, USA, 2016; pp. 215-239.

118. Ronald, P.C.; Beutler, B. Plant and animal sensors of conserved microbial signatures. Science 2010, 330, 1061-1064. [CrossRef]

119. Jacob, F.; Vernaldi, S.; Maekawa, T. Evolution and conservation of plant NLR functions. Front. Immunol. 2013, 4, 297. [CrossRef]

120. Jones, J.D.G.; Dangl, J.L. The plant immune system. Nature 2006, 444, 323-329. [CrossRef] [PubMed]

121. Elinav, T.; Strowig, J.; Henao-Mejia, J.; Flavell, R.A. Regulation of the antimicrobial response by NLR proteins. Immunity 2011, 34, 665-679. [CrossRef] [PubMed]

122. Garcia, A.V.; Charriera, A.; Schikorab, A.; Bigearda, J.; Pateyronc, S.; de Tauzia-Moreaua, M.L.; Evrard, A.; Mithöfer, A.; Martin-Magniette, M.L.; Virlogeux-Payant, I.; et al. Salmonella enterica Flagellin Is Recognized via FLS2 and Activates PAMP-Triggered Immunity in Arabidopsis thaliana. Mol. Plant 2014, 7, 657-674. [CrossRef] [PubMed]

123. Iriti, M.; Franco, F. Review of innate and specific immunity in plants and plant. Mycopathologia 2007, 164, 57-64. [CrossRef] [PubMed]

124. Thomma, B.P.H.J.; Cammue, B.P.A.; Thevissen, K. Plant defensins. Planta 2002, 216, 193-202. [CrossRef] [PubMed]

125. Kroupitski, Y.; Golberg, D.; Belausov, E.; Pinto, R.; Swartzberg, D.; Granot, D.; Sela, S. Internalization of Salmonella enterica in leaves is induced by light and involves chemotaxis and penetration through open stomata. Appl. Environ. Microbiol. 2009, 75, 6076-6086. [CrossRef] [PubMed]

126. Berger, C.N.; Shaw, R.K.; Brown, D.J.; Mather, H.; Clare, S.; Dougan, G.; Pallen, M.J.; Frankel, G. Interaction of Salmonella enterica with basil and other salad leaves. ISME J. 2009, 3, 261-265. [CrossRef]

127. López-Gálvez, F.; Gil, M.I.; Allende, A. Impact of relative humidity, inoculum carrier and size, and native microbiota on Salmonella ser. Typhimurium survival in baby lettuce. Food Microbiol. 2018, 7, 155-161. [CrossRef] 
128. Brunner, F.; Fraiture, M. Killing two birds with one stone: Trans-kingdom suppression of PAMP/MAMP-induced immunity by T3E from enteropathogenic bacteria. Front. Microbiol. 2014, 5, 320. [CrossRef]

129. Neumann, C.; Fraiture, M.; Hernàndez-Reyes, C.; Akum, F.N.; Virlogeux-Payant, I.; Chen, Y.; Pateyron, S.; Colcombet, J.; Kogel, K.H.; Hirt, H.; et al. The Salmonella effector protein SpvC, a phosphothreonine lyase is functional in plant cells. Front. Microbiol. 2014, 5, 548. [CrossRef]

130. Brown, N.A.; Urban, M.; Hammond-Kosack, K.E. The trans-kingdom identification of negative regulators of pathogen hypervirulence. FEMS Microbiol. Rev. 2016, 40, 19-40. [CrossRef]

131. Heffron, F.; Niemann, G.; Yoon, H.; Kidwai, A.; Brown, R.; McDemrott, J.; Smith, R.D.; Adkins, J.N. Salmonella-secreted virulence factors. In Salmonella from Genome to Function; Porwollik, S., Ed.; Caister Academic Press: San Diego, CA, USA, 2011; pp. 187-223.

132. Schikora, A.; Virlogeux-Payant, I.; Bueso, E.; Garcia, A.V.; Nilau, T.; Charrier, A.; Pelletier, S.; Menanteau, P.; Baccarini, M.; Velge, P.; et al. Conservation of Salmonella infection mechanisms in plants and animals. PLoS ONE 2011, 6, e24112. [CrossRef] [PubMed]

133. Shirron, N.; Yaron, S. Active suppression of early immune response in tobacco by the human pathogen Salmonella Typhimurium. PLoS ONE 2011, 6, e18855. [CrossRef] [PubMed]

134. Galan, J.E. Common themes in the design and function of bacterial effectors. Cell Host Microbe 2009, 5, 571-579. [CrossRef] [PubMed]

135. Potnis, N.; Soto-Arias, J.P.; Cowles, K.; van Bruggen, A.H.C.; Jones, J.B.; Barak, J.D. Stealth colonization of tomato leaf by Xanthomonas perforans enhances persistence of Salmonella enterica in the phyllosphere. Appl. Environ. Microbiol. 2014, 80, 3173-3180. [CrossRef]

136. Monack, D.M.; Mueller, A.; Falkow, S. Persistent bacterial infections: The interface of the pathogen and the host immune system. Nat. Rev. Microbiol. 2004, 2, 747-765. [CrossRef] [PubMed]

137. Parker, C.T.; Sperandio, V. Cell-to-cell signalling during pathogenesis. Cell Microbiol. 2009, 11, $363-369$. [CrossRef]

138. Bulgari, D.; Casati, P.; Crepaldi, P.; Daffonchio, D.; Quaglino, F.; Brusetti, L.; Bianco, P.A. Restructuring of endophytic bacterial communities in grapevine yellows-diseased and recovered Vitis vinifera L. plants. Appl. Environ. Microbiol. 2011, 77, 5018-5022. [CrossRef]

139. Cardenas, A.; Rodriguez, R.L.; Pizarro, V.; Cadavid, L.F.; Arevalo-Ferro, C. Shifts in bacterial communities of two Caribbean reef-building coral species affected by white plague disease. ISME J. 2012, 6, 502-512. [CrossRef]

140. Casadevall, A.; Pirofski, L.A. Host-Pathogen interactions: Basic concepts of microbial commensalism, colonization, infection, and disease. Infect. Immun. 2000, 68, 6511-6518. [CrossRef]

141. Rosas-Magallanes, V.; Deschavanne, P.; Quintana-Murci, L.; Brosch, R.; Gicquel, B.; Neyrolles, O. Horizontal Transfer of a Virulence Operon to the Ancestor of Mycobacterium tuberculosis. Mol. Biol. Evol. 2006, 23, 1129-1135. [CrossRef] [PubMed]

142. Kelly, B.G.; Vespermann, A.; Bolton, D.J. Horizontal gene transfer of virulence determinants in selected bacterial food borne pathogens. Food Chem. Toxicol. 2009, 47, 969-977. [CrossRef] [PubMed]

143. Xu, H.; Qin, S.; Lan, Y.; Liu, M.; Cao, X.; Qiao, D.; Cao, Y.; Cao, Y. Comparative genomic analysis of Paenibacillus sp. SSG-1 and its closely related strains reveals the effect of glycometabolism on environmental adaptation. Sci. Rep. 2017, 7, 5720. [CrossRef] [PubMed]

144. Padda, K.P.; Puri, A.; Chanway, C.P. Paenibacillus polymyxa: A prominent biofertilizer and biocontrol agent for sustainable agriculture. In Agriculturally Important Microbes for Sustainable Agriculture; Meena, V., Mishra, P., Bisht, J., Pattanayak, A., Eds.; Springer: Singapore, 2017; Volume 2, pp. 165-191.

145. Mikkola, R.; Andersson, M.A.; Grigoriev, P.; Heinonen, M.; Salkinoja-Salonen, M.S. The toxic mode of action of cyclic lipodepsipeptide fusaricidins, produced by Paenibacillus polymyxa, toward mammalian cells. J. Appl. Microbiol. 2017, 123, 436-449. [CrossRef] [PubMed]

(c) 2019 by the authors. Licensee MDPI, Basel, Switzerland. This article is an open access article distributed under the terms and conditions of the Creative Commons Attribution (CC BY) license (http:/ / creativecommons.org/licenses/by/4.0/). 